\title{
THE NEOLITHIC OF THE BALIKH VALLEY, NORTHERN SYRIA : A FIRST ASSESSMENT
}

\author{
P.M.M.G. AKKERMANS
}

ABSTRACT. - This article discusses in short the evidence for Neolithic occupation in the Balikh valley of northern Syria. Recent excavations and surveys in the region have yielded a wealth of new data, allowing a more detailed insight into cultural developments in this little known part of Syria.

RÉSUMÉ. - Cet article présente un aperçu des recherches récentes sur le Néolithique dans la vallée du Balikh (Syrie du Nord). Fouilles et prospections ont livré de nouvelles données qui permettent d'améliorer notre vision de l'évolution culturelle de cette région encore mal connue de la Syrie.

\section{INTRODUCTION}

In Syrian archaeology, the Balikh valley has gone unexplored for a long time. In 1938, Mallowan visited the valley and, within a six-week campaign, laid out trenches at five sites (1). At two of these mounds, viz. tells Aswad and Ibn es-Shehab, Neolithic remains were found although at the latter site unfortunately in a disturbed context. Over 30 years later, in 1970, Mallowan's Tell Aswad was reexcavated by J. Cauvin who renamed the site to Tell Assouad. Cauvin found a long sequence of eight occupation levels belonging to the later 7th millennium B.C. (2).

In 1978, a French-British team undertook a rapid survey of the Balikh valley and reported on a number of prehistoric sites, some of which were not known before (3). This survey was the first which truly acknowledged the importance of the Balikh valley in prehistoric times. Some decades before, Mallowan (4) considered the valley as being a cultural backwater but Copeland's reports have clearly shown that this picture is far from correct. Our own research in this region closely adheres to Copeland's conclusions. Since 1981 the University of Amsterdam is involved in archaeological work in the Balikh valley. Excavations have been carried out at tells Hammam et-Turkman, Damishliyya and Sabi Abyad, all of which yielded prehistoric remains. At Tell Hammam et-Turkman late 5th and 4th millennium layers have been unearthed (5), whereas at Damishliyya mainly remains belonging to the 7th millennium B.C. were found (6). At Tell Sabi Abyad until now solely layers dating to the second half of the 6th millennium have

(1) MALLOWAN, 1946.

(2) CAUVIN J., 1972, 1974

(3) COPELAND, 1979, 1982

(4) MALLOWAN, $1946: 115$

(5) VAN LOON, 1988.

(6) AKKERMANS, 1988. been uncovered (7), but it is expected that future work at the site will yield a continuous sequence of occupation from the 7 th into the 6th millennium B.C. A survey undertaken in 1983 gave evidence of a large number of prehistoric sites and suggested a continuous occupation of the Balikh valley at least from the late 8 th or early 7 th millennium onwards (8).

This paper intends to give a tentative outline of Neolithic developments in the Balikh valley (ca. 8000-4500 B.C.). Earlier, Copeland (9) has given a skilful discussion of prehistoric trends in the region but recent research has yielded much new information, thus allowing a more refined picture.

\section{THE NATURAL SETTING}

The Balikh valley was formed at the start of the upper Pleistocene. Originally, the Balikh in its lower course flowed to the west, following the wadi alFayd into the Euphrates valley. Due to tectonic movements along the Euphrates fault towards the end of the upper Pleistocene, the Balikh changed its course to the east, thereby cutting through Euphrates deposits and creating a floodplain about $1 \mathrm{~km}$ wide. Generally, the Balikh plain is about 4 to $6 \mathrm{~km}$ wide although in two areas, viz. in the north, the region east of the modern village of Hammam et-Turkman, and, in the south, at the confluence of old and recent Balikh, the valley widens into a broad plain over $12 \mathrm{~km}$ wide. Except in the latter areas, the valley is generally bordered by steep gravel terraces rising 10 to $30 \mathrm{~m}$ above the plain. The Balikh basin consists of Holocene deposits having a thickness of 5 to $10 \mathrm{~m}$ and mainly built up of brown fluviatile-aeolithic loams. Most ancient settlements are situated on these

(7) AKKERMANS, 1987a, 1987b.

(8) AKKERMANS, 1984 and forthcoming.

(9) COPELAND, 1979 
Holocene deposits; the Pleistocene terraces, apart from Palaeolithic occupation, were mainly used for the construction of Roman-Parthian cemeteries.

The river Balikh is a small stream having an average width of about $6 \mathrm{~m}$. Only near its main spring at Ain al-Arous near the Syro-Turkish border the river is considerably wider. The Balikh is a perennial tributary of the Syrian Euphrates. The average flow of the Balikh is about $6 \mathrm{~m}^{3} / \mathrm{sec}$ which is very low when compared with the Euphrates or the - Khabur that have an average flow of about $840 \mathrm{~m}^{3} / \mathrm{sec}$ and $50 \mathrm{~m}^{3} / \mathrm{sec}$ respectively. Only after the winter rains the flow of the Balikh may increase to about $12 \mathrm{~m}^{3} / \mathrm{sec}$. Nowadays, in summer large parts of the Balikh are completely dry.

The Balikh plain is drained by numerous channels and wadis, some of which are very large. Occasionally, a diffuse river pattern occurs, dividing the water of the Balikh over numerous channels and thus creating a highly inaccessible, often swampy area (10),

The Balikh valley roughly lies between the 200 and $300 \mathrm{~mm}$ isohyets. The average annual rainfall varies from $183 \mathrm{~mm}$ at Raqqa on the Euphrates to $275 \mathrm{~mm}$ at Tell Abyad near the Syro-Turkish border. Nowadays, the crucial $250 \mathrm{~mm}$ isohyet, running east-west somewhere near the confluence of Balikh and its main tributary wadi Qaramokh, divides the valley into two zones of widely different land-use. The northern parts of the Balikh region are suitable for dry-farming but in the south agriculture necessitates irrigation. The present-day valley is almost entirely used for agricultural purposes and virtually devoid of trees. Only along the river one may find some poplar and willow, with an undergrowth of marsh plants.

\section{EXCAVATIONS AT TELL ASSOUAD}

Tell Assouad is situated on a protruding terrace remnant on the east bank of the river Balikh. The complex consists of two mounds divided from each other by means of a low saddle. The main mound, immediately next to the river, is about $150 \mathrm{~m}$ in diameter and about $12 \mathrm{~m}$ high. The other mound, situated ca. $70 \mathrm{~m}$ further north, has a diameter of about $100 \mathrm{~m}$ and is ca. $5 \mathrm{~m}$ high. On the basis of surface finds, both mounds seem to have been occupied simultaneously. So far, excavations have been carried out solely on the main mound. In 1938 Mallowan carried out a small sounding on top of the mound, thereby exposing parts of a rectangular structure built of narrow rooms (11). The presence of an oxskull across the threshold of a doorway led Mallowan

(10) MALLOWAN, 1946

(11) Ibid. to the conclusion that this building probably had served as a shrine. Moreover, Mallowan suggested a date in the Halaf period for this building on the basis of some sherds found in its fill. In addition to these sherds, however, a number of flint and obsidian implements were found, some of which show close similarities to the Levantine Byblos Points, thus indicating a date in the 7 th millennium B.C. Copeland (12) already suggested that Mallowan's building probably is of an earlier date than the Halaf sherds found at the site. In 1970, J. Cauvin reexcavated Tell Assouad by means of a stepped trench along the steep northern slope of the mound (13). This trench yielded from top to base exclusively 7 th millennium remains. Some Halaf sherds, belonging to the later stages of the Neolithic period, were found solely on the surface of the mound. Surprisingly enough, Cauvin found that the basal levels VIII-VII at Assouad were without architecture but with pottery, whereas the upper levels VI-I yielded mud-brick remains but no ceramics ! Whether these remarkable finds, however, give a correct picture of Neolithic developments at the site is doubtful. Le Mière (14) already pointed out that probably sampling procedures account for the differences observed.

The ceramics from Assouad VIII-VII are coarse products, the majority of which is plant-tempered. Most sherds have a dark core. Burnishing commonly appears. A few sherds showed traces of red paint, but most characteristic seems to be an applied band of clay underneath the rim. Shapes mainly point to simple hole-mouth pots, straight-walled bowls and low plates. Many vessels had loop handles, some of which were very large. Ledge handles appear, too, but are much less common. Originally, Cauvin (15) suggested a close relationship between the pottery from Tell Assouad and that of the Amuq phases A-B, but a more detailed analysis (16) has shown that the ceramics from Assouad and the Amuq have little in common, the former no doubt preceding the Amuq wares. This is also indicated by a number of radiocarbon dates from Tell Assouad levels VIII and III, which gave a date around 6500 B.C. (17). According to some dates from Ramad III and Labwe II A, Amuq A pottery appears in the early 6 th millennium, viz. around 6000-5900 B.C. (18).

Other finds at Tell Assouad include numerous fragments of well-made alabaster or marble bowls, some bone implements, some stylised figurines of baked clay or limestone, and many flint and obsidian implements. Obsidian seems to be most common in the lower ceramic Neolithic levels VIII-VII and de-

\footnotetext{
(12) COPELAND, $1979: 269$

(13) CAUVIN J., 1972.

(14) LE MIERE, 1979 : 40.

(15) CAUVIN J., 1972: 89.

(16) LE MIERE, 1979, 1986.

(17) CAUVIN J., $1974: 203$.

(18) See MOORE, 1982.
} 


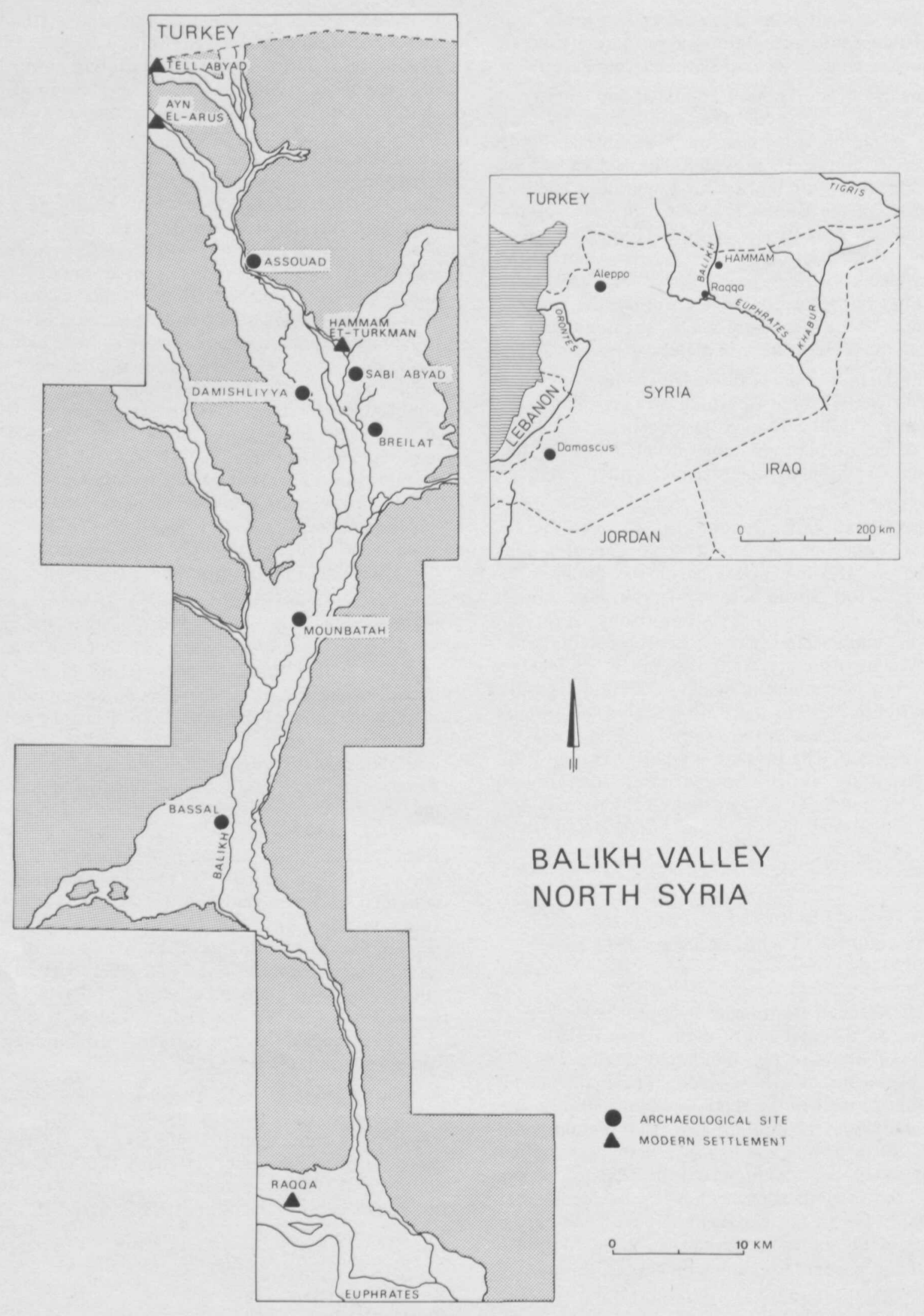

FIG. 1. - Map of the Balikh valley with (inset) its location in Syria.

124 
creases in importance in the upper levels (19). The lithic industry includes burins, end-scrapers, sickleblade elements and arrowheads, the latter all of Byblos Point-typè. The lithics indicate a clear relationship between the basal ceramic Neolithic levels VIII-VII and the upper, supposedly aceramic, Neolithic levels VI-I, thus strongly suggesting a continuous occupation of the site through time.

\section{EXCAVATIONS AT TELL DAMISHLIYYA (20)}

Tell Damishliyya is a small mound measuring about $60 \times 70 \mathrm{~m}$, with a height of about $5 \mathrm{~m}$. The site is located on the west bank of the river Balikh, ca. $12 \mathrm{~km}$ south of Assouad. Like the latter, Damishliyya is situated on a protruding terrace remnant immediately next to the river. Excavations here in 1984 gave evidence of a small Neolithic settlement covering about 0.4 ha. Probably Damishliyya was inhabited by 20 to 30 persons at most.

The soundings at Damishliyya revealed an uninterrupted sequence of seven building levels (strata 1 to 7). Virgin soil has not yet been reached and about $1 \mathrm{~m}$ of occupational remains is expected to be present below the earliest stratum reached. All strata yielded traces of mud-brick architecture but only the building remains of the lower stratum 2 were exposed on a larger scale. Here parts of a rectangular building appeared, consisting of a series of narrow rooms which were probably used for storage. All walls were erected upon a platform of large mud bricks (up to $60 \times 40 \mathrm{~cm}$ ). These bricks were apparently reused as indicated by traces of white plaster on the sides of one of the bricks. Similar reused bricks appeared in the walls of the building.

At Damishliyya pottery was found solely in the upper strata 3-7. The pottery from Damishliyya is virtually identical to that from Tell Assouad although some local peculiarities are observed; the latter, however, are expected within a domestic mode of production. Thus, whereas at Assouad about $14 \%$ of the ceramics showed solely mineral temper, at Damishliyya hardly $1 \%$ of the ceramics indicated such grit inclusions. Moreover, at Assouad some Neolithic painted sherds were found which were absent at Damishliyya. Absent at Damishliyya were also the pots with cordon decoration that constitute a characteristic trait at Tell Assouad.

Other parallels between Assouad and Damishliyya include the small "stud" figurines, the stone bowls, and the bone and lithic implements. As at Assouad, numerous arrowheads of Byblos Point-type, burins, sickle blades, etc. were found at Damishliyya. So far, no Amuq points were recovered from

(19) CAUVIN M.-C., $1972: 90$.

(20) AKKERMANS, 1988.
Assouad, but at Damishliyya two such points were collected from the surface.

Around 6000 B.C. Damishliyya was deserted. Some incised sherds and some Amuq points found at the surface of the mound point towards an early 6 th millennium occupation but so far no substantial traces of such inhabitation have been found. In the first half of the 5th millennium a small Halaf settlement was founded. The latter may represent a Halaf camp site used during a short period only.

\section{SOME CHRONOLOGICAL REMARKS}

From the foregoing it is clear that the remains uncovered at Assouad and Damishliyya are highly identical and no doubt both sites were simultaneously occupied. A major difference, however, between both sites is the appearance of pottery. Whereas until now at Assouad pottery was solely found in the basal levels and apparently was absent in the upper levels, at Damishliyya the reverse is the case : here pottery was found in ever increasing numbers in the upper strata, whereas the lower strata 1-2 were wholly devoid of ceramics. The question whether at Assouad the ceramics represent an intermittent stage (21) or whether its absence in the upper levels is largely due to matters of sampling (22) is hard to answer but the evidence from Damishliyya and, on the Syrian Euphrates, from Abu Hureyra points in the latter direction. At Abu Hureyra small quantities of pottery were found in the topmost levels (phase III), marked by some mud-brick walls and numerous shallow pits filled with occupation debris. The latest radiocarbon date from the lower aceramic levels is $6240 \pm 77$ B.C. and soon afterwards the first ceramics appeared at the site (23). The pottery from Abu Hureyra consists of a plain coarse ware, being strawtempered and crumbly in texture. Most of the sherds seem to have been burnished to some degree and some sherds showed traces of red paint. Some others indicated a cordon decoration. Both painted and cordon decoration were not found at Damishliyya but do appear at Tell Assouad (24). In general, the pottery from Abu Hureyra seems to be closely related to that from the Balikh sites.

In northern Syria, pottery seems to appear at an early stage. At Mureybit some small containers of baked clay were found already in phase III, to be dated around 8000-7600 B.C. (25). At Tell Assouad pottery seems to appear around 6500 B.C. , whereas at Abu Hureyra pottery is found around 62006000 B.C. (26). True pottery manufacture seems to

(21) CAUVIN J., 1974.

(22) LE MIÈRE, 1979, 1986.

(23) MOORE, 1982, 15.

(24) LE MIÈRE, 1979

(25) CAUVIN J., 1974.

(26) MOORE, 1982. 
hav started in the second half of the 7 th millennium in the Balikh and Euphrates region. It has been claimed (27) that the pottery from the Balikh sites and its equivalent at Abu Hureyra strongly compares with the ceramics found at Bouqras in eastern Syria, but Le Mière (28) has clearly shown that the Bouqras pottery is of a different tradition and most closely resembles the ceramics of sites like Umm Dabaghiyah, Tell Sotto and Yarim Tepe I. Pottery at Bouqras appears in mixed deposits in the «virgin soil squares» from level 7 onwards, but the greater part of it was found in the topmost southwestern part of the site (29). A number of radiocarbon dates from Bouqras suggests that the pottery found in the upper levels 7-1 of the "virgin soil squares" can be dated around 6100-5900 B.C., whereas the ceramics from the southwestern area are of a considerably later date, viz. around 5600-5500 B.C. (30). Probably, the pottery found at Bouqras for the larger part succeeds that recovered from Assouad, Damishliyya and Abu Hureyra.

A chronological assignment of Assouad and Damishliyya to the later 7 th millennium is confirmed by the lithic implements and other small finds from these sites. Others (31) have already pointed out that the lithic industry of Assouad and, consequently, of Damishliyya, entirely fits within the Levantine PPNB tradition, in inland Syria further represented by sites like Mureybit IV, Abu Hureyra and Bouqras. Most characteristic are the tanged arrowheads of Byblos Point-type, found in a stratigraphic context both at Assouad and Damishliyya and, on the surface, at numerous other sites in the Balikh region. Byblos Points have a long range in time; they first seem to appear around 7600 B.C. and last until the early 6 th millennium B.C. (32). On the Euphrates, towards the end of the 7th millennium a new type of arrowheads appeared, viz. the Amuq Points. At Abu Hureyra these points were only found in the upper phase III, marked by the first appearance of pottery at the site (33). Further east, at Bouqras arrowheads of Amuq type were found throughout the sequence in association with Byblos Points (34). On the Balikh, both Assouad and Damishliyya did not yield Amuq arrowheads in a stratigraphic context, but two such points were found on the surface of Damishliyya.

The carefully made stone bowls found at Assouad and Damishliyya closely compare with stone vessels from Bouqras. At the latter site, multi-coloured stones were worked in such a way that the natural banding or other colour effects served as

(27) CAUVIN J., 1974; MOORE, 1975, 1982; COPELAND, 1979.

(28) LE MIÈRE, 1983, 1986.

(29) LE MIÈRE, 1986.

(30) Ibid. : 120-21; 253-57.

(31) CAUVIN M.-C., 1972; COPELAND, 1979.

(32) See MOORE, 1982.

(33) MOORE, $1975: 63$

(34) ROODENBERG, $1986: 44$ decoration of the vessel wall. This seems to be the case, too, in the Balikh valley. A fragment of a small pot with legs found in stratum 3 at Damishliyya constitutes another parallel to Bouqras stone ware (35).

\section{EXCAVATIONS AT TELL SABI ABYAD}

Tell Sabi Abyad is situated in the undulating plain south of the modern village of Hammam etTurkman, at a distance of about $5 \mathrm{~km}$ from the river Balikh. The surroundings of the site consist of highly arable lands drained by various wadis. Originally, the Nahr et-Turkman, a branch of the Balikh, probably flowed immediately next to the mound. Sabi Abyad is the largest of four prehistoric mounds located in a linear pattern at short distances from each other. Excavations carried out in 1986 at Sabi Abyad showed that the mound itself, too, consists of at least four smaller mounds (36). Tell Sabi Abyad was occupied throughout the 6th millennium B.C. and probably also in the later 7 th millennium B.C. The other mounds include two aceramic Neolithic sites and one late $\mathrm{Ha}$ laf settlement.

So far, the trenches laid out at the site have yielded solely late 6th millennium remains (53005000 B.C.). At present, two main periods are indicated, termed Late Neolithic and Early $\mathrm{Ha}$ laf (37). Late Neolithic (= pre-Halaf) remains have been uncovered on a limited scale both on the northeastern and southeastern parts of the mound. Whereas in the former area Late Neolithic levels appear immediately below the top soil, in the southeastern area these levels are deeply buried underneath Halaf strata. Architectural remains recovered until now are poor, although a well-laid stone foundation suggests that more substantial architecture is present as well. Large numbers of ceramics have been recovered, which differ strongly from those of the 7th millennium sites of Assouad and Damishliyya. In general, the pottery is coarsely made and straw-tempered, displaying simple shapes. About one quarter of the pottery is burnished. Some sherds are incised. Interesting is the appearance of some "husking tray" fragments, showing either ridges or impressed roun-

(35) See ROODENBERG, 1986.

(36) AKKERMANS, 1987a, $1987 \mathrm{~b}$.

(37) This terminology may cause some confusion since our "Late Neolithic" actually is not the latest Neolithic phase; the latter is considered to be represented by the Halaf culture. Although it has been suggested (MELLAART, 1970, 1981; COPELAND, 1979) to define painted pottery societies like Halaf as "Chalcolithic", I here follow BRAIDWOOD and HOWE (1960), thereby considering Halaf settlements like Sabi Abyad as advanced farming villages (See REDMAN, 1978 : 177). Moreover, the excavations at Tell Sabi Abyad have given evidence of a close relationship between the Late Neolithic and Early Halaf periods, the characteristic traits of the latter period probably being a local development of earlier Late Neolithic features. 
ded pits. Beside the bulk of coarse ware ceramics, small numbers of more carefully produced greyblack, often burnished pottery appear, together with painted ceramics. The latter are occasionally incised, too. Although locally made, the painted or paintedand-incised pottery all seems to be of Samarra derivation. Apparently, Samarra influences reached the Balikh valley at an early stage and definitely preceded the appearance of Halaf in the region.

Early Halaf levels were found at Sabi Abyad immediately above the Late Neolithic strata. Whereas in the northeastern areas of the site the Early Halaf levels probably were divided from the Late Neolithic strata by a hiatus, in the southeastern area no such break in occupation seems to be present. Here the Halaf levels comprise an accumulation over $3 \mathrm{~m}$ thick, yielding remains of both rectangular and round mud-brick buildings. The latter structures are all about $3 \mathrm{~m}$ in diameter and, most characteristically, all have a burnt interior wall and floor plaster. No doubt, this burning was intentional and probably meant to create a very hard, vermin-resistant plaster. The presence of large quantities of carbonised wheat around several of these buildings suggests that they were used primarily for storage purposes. The rectangular houses were built of a number of long but narrow rooms, sometimes containing an oven. Occasionally, the exterior walls were reinforced by buttresses. Generally, the present evidence from Tell Sabi Abyad suggests that occupation was open and consisted of few buildings only. Our soundings point towards isolated house complexes, each consisting of a rectangular central building surrounded by rectangular and round annexes. Perhaps the site as a whole was covered by only four or five of such isolated house complexes, thus implying a rather small population.

The strata immediately following the Late Neolithic levels in the southeastern area seem to represent a transitional stage between the Late Neolithic and Early Halaf periods at the mound. In these transitional strata, coarse ware ceramics are still found in considerable quantities, but painted Halaf pottery now includes over $60 \%$ of the sherds recovered. In the upper strata, the amount of painted Halaf pottery rapidly increases and coarse ware pottery now hardly accounts for $10-15 \%$. Most interesting is the continuous occurrence of Samarra pottery (or Samarra derivatives). This kind of ceramics was already found in moderate quantities in the strata preceding the appearance of Halaf at the site and seems to have strongly influenced the development of the latter. Many sherds, at first sight hardly distinguishable from Halaf pottery, after a more careful look display clear Samarra decorative traits in combination with Halaf features. Apparently, Halaf pottery did not appear fully developed in the Balikh region, but grew out of an earlier Samarra-related tradition. It is suggested that Halaf is an indigenous development in the Balikh valley, perhaps representing a local ans- wer to continuous Samarra influences from the east. Samarra traits were transformed according to local standards of manufacture and decoration. A local development is also indicated by the lithic implements from Sabi Abyad. Copeland (38) has pointed out that both the Late Neolithic and Early Halaf lithic industries at Tell Sabi Abyad are very similar and on typological grounds can be assigned to the Amuq B of the Levant. Finally, the lack of a hiatus in the stratigraphic record suggests a continuous occupation of the site and also points towards a strong relationship between the Late Neolithic and Early Halaf periods.

A date in the later part of the 6 th millennium B.C. is suggested here for the Early Halaf occupation at Tell Sabi Abyad. Some radiocarbon samples were taken, but no laboratory results are available yet. Chronologically, both the Late Neolithic and Early Halaf phases at Sabi Abyad can be related to the Amuq B, although true parallels are sparse. Some Dark-Faced Burnished Ware is present at Sabi Abyad and probably represents import products from western Syria or Cilicia (39). A few pattern-burnished sherds have been found, which are considered to be a characteristic feature of phase B in the Amuq (40). Closest parallels to Sabi Abyad are probably found in the upper Khabur region, at sites like Tell $\mathrm{Ha}$ laf (41) and Tell Habesh (42). At these sites, the basal levels seem to contain exclusively Altmonochrome pottery, followed by transitional levels showing a mixture of both Altmonochrome and painted Halaf pottery, until in the upper levels the Altmonochrome finally disappears. At Tell Halaf, a radiocarbon sample suggests a date around 5600 B.C. for the transitional levels at the site (43). At nearby Tell Aqab, the lowest levels yielded Early Halaf pottery which seems to be closely related to that from Sabi Abyad. These early levels at Tell Aqab also contained a large amount of coarse straw-tempered and burnished pottery which is compared with the Altmonochrome from Tell Halaf (44). Pre-Halaf levels, however, do not seem to be present at Tell Aqab.

\section{NEOLITHIC SUBSISTENCE ECONOMY IN THE BALIKH VALLEY}

The three Neolithic sites excavated so far in the Balikh valley have all yielded some zoological and/or botanical information, thus allowing a first insight into Neolithic subsistence activities in the region.

(38) COPELAND, 1989

(39) See LE MIÈRE, 1989.

(40) BRAIDWOOD and BRAIDWOOD, $1960: 73$,

(41) von OPPENHEIM, 1943.

(42) DAVIDSON, 1977.

(43) VOGEL and WATERBOLK, 1964: 355.

(44) DAVIDSON and WATKINS, 1981. 
At Tell Assouad, no seeds or the like were recovered; only the zoological remains have been collected. Mallowan (45) already shortly reported on the presence of bones of pigs, sheep or goats, cattle and some small Equus in the house which he partly uncovered on top of the mound. A more detailed study (46) is available for the bones found by Cauvin in his stepped trench. Helmer noted 11 species, some of which (viz. Canis, Meles, Vulpes, Equus, Dama and Cervus) were represented by very few fragments only. The bulk of the bones belonged to sheep or goats, cattle, pigs and gazelle. As expected, sheep or goats are most common (numbers varying from $60 \%$ in levels VIII-VII to $79.5 \%$ in level I) and both seem to have been domesticated. The other species found at Assouad all seem to have been wild and, although already some herding may have taken place, most of them probably were obtained by hunting. Hunting seems to have been of extreme importance in levels VI-V at Assouad where almost three quarters of the bones recovered probably belong to wild animals. Pigs, cattle and particularly gazelle are now most abundantly present, the latter species accounting for over $40 \%$ of the bones found. In the upper levels, the amount of gazelle sharply decreases to only $3.9 \%$ in level I. The emphasis upon hunting and the concomitant disappearance of pottery and of armatures de faucilles à dos convexe in levels VI-V at Assouad leads Helmer (47) to the conclusion that at this time the population of the site is replaced by another, thereby introducing a different economic organisation. However, others (48) have already pointed out that hunting, in combination with plant gathering, may have been of ultimate importance in times of dearth (wild animals and plants serve as buffer resources). I suggest that levels VI-V at Assouad do not represent a shift in population but a period of unfavourable living conditions, during which the inhabitants of the site relied heavily upon the wild resources surrounding them.

At Damishliyya both bones and some plant remains were recovered, but so far only the latter have been studied (49). The plant remains are of mixed origin and do not represent a specific activity or stage in crop processing. Cereals and pulse seeds are predominant. Halstead (50) has suggested that the cultivation of cereals and pulses in small gardens on a more or less permanent basis could have provided the bulk of both calory and protein requirements of small Neolithic societies. In the case of Damishliyya, the necessary plant food probably was obtained by dry-farming in the immediate vicinity of the site. Although nowadays dry-farming is widely practised in the area, the danger of crop failure due to fluctua-

(45) MALLOWAN, $1946: 124$

(46) HELMER, 1985.

(47) Ibid. : 282.

(48) e. g. HALSTEAD and JONES, $1980: 106$

(49) VAN ZEIST et al, 1988.

(50) HALSTEAD, 1981. tions in annual precipitation is considerable. It has, however, been suggested that in the early Holocene, ca. 9000-6000 B.C., climatic conditions in northern Syria were more humid than nowadays, thus yielding a firmer basis for dry-farming (51). Cereals include the larger part (about $70 \%$ ) of the carbonised seeds recovered at Damishliyya. Emmer wheat (Triticum dicoccum) is most abundantly present, but other species of wheat (Triticum durum/aestivum) are found, too. Einkorn wheat (Triticum monococcum), however, seems to be absent. Two-rowed barley (Hordeum distichum) is found, although in small quantities. Pulses include about $23 \%$ of the seeds found at Damishliyya and are represented by lentils, bitter vetch and, particularly, peas. Linseed (Linum usitatissimum) was also present. Apparently flax was grown, either for the oleaginous seeds, the fibres or a combination of these (52).

At Sabi Abyad, emmer wheat is the main cereal found. Einkorn wheat and barley appeared only in low quantities (53). Charred remains of emmer wheat were found in pits and around some tholoi and probably represent parts of burnt stock piles. Pulse crops seem to be of minor importance at Tell Sabi Abyad. Lentil (Lens culinaris) was definitely cultivated and field pea (Pisum sativum) was grown, too, although in very small quantities. A single specimen of bitter vetch (Vicia ervilia) appeared, but since this species also occurs as a field weed, it is unknown whether bitter vetch was cultivated. Flax (Linum usitatissimum) was grown, although on a limited scale. The faunal assemblage of Tell Sabi Abyad indicates a stable agrarian system with an emphasis on ovicaprid breeding, supplemented by some cattle and pig breeding (54). Over $95 \%$ of the bones recovered at Tell Sabi Abyad belonged to domestic animals. Hunting played a minor role. Few bones were found of an equid, presumably the onager (Equus hemionus), and of gazelle (Gazella sp.), fallow deer (Dama mesopotamica) and roe (Capreolus capreolus). Also an ulna of a badger (Meles meles) appeared. Unio shells are frequently found and suggest that the gathering of fresh-water molluscs was a common practice. Originally, Tell Sabi Abyad was probably situated along a branch of the Balikh, thus enabling gathering in the immediate vicinity of the settlement.

Combining the present evidence from the sites excavated, a picture emerges of small communities exploiting the natural environment in a widely varied way. The settlements were situated immediately next to the Balikh or associated water-courses. Reeds and wood, used in house construction and as fuel, could easily be obtained from the marshy flood-plain. This is also a suitable area for fowling, fishing and gathering of molluscs. Moreover, since the Balikh is

(51) VAN ZEIST and WOLDRING, 1980.

(52) VAN ZEIST et al, 1988.

(53) VAN ZEIST and WATERBOLK-VAN ROOYEN, 1989.

(54) VAN WIJNGAARDEN-BAKKER, 1989. 
the main source of water in the region, it will have attracted game (gazelle, roe etc.) as well. Domestic animal breeding, however, by far exceeded the importance of hunting. Sheep and goat are most common, followed by cattle and pig. Flocks were probably herded at some distance away from the settlements, not only in search of good grazing grounds but also to prevent the animals from ruining the fields or gardens. Emmer wheat and, to a lesser degree, other species of wheat and barley were cultivated together with several pulses probably in small gardens in the immediate surroundings of the site. Pulses seem to decrease in importance towards the end of the 6th millennium. Gathering of wild fruits and other plant food was hardly practised. At Tell Sabi Abyad, few remains of pistachio, almond, prune and fig were found.

\section{NEOLITHIC SETTLEMENT IN THE BALIKH VALLEY}

Until now, no complete sequence of the Neolithic period is available for the Balikh valley. The three Neolithic sites excavated so far have covered solely the later stages of the Neolithic, viz. the ceramic Neolithic, but even the latter still shows some gaps. Apart from the aceramic period, we still lack in our stratigraphic record the first half of the 6 th millennium and the later part of the first half of the 5 th millennium (Late Halaf). It is hoped that future work at Tell Sabi Abyad and immediate surroundings will yield materials belonging to these phases, thus closing the present hiatuses.

Truly aceramic Neolithic remains have been found in a stratigraphic context only at Damishliyya (the lower strata 1-2). The so-called aceramic levels at Tell Assouad succeed the introduction of pottery at the site and at least chronologically fit within the ceramic Neolithic period.

Surveys have given ample evidence of Neolithic settlements in the Balikh valley. L. Copeland (55) already stressed the importance of the valley during the 7 th to 4 th millennia B.C. and the 1983 University of Amsterdam survey wholly confirmed this view (56). At present, more than 20 sites are ascribed to the 7th millennium B.C. or earlier (fig. 2). Sites yielding pottery comparable to that from Assouad and Damishliyya are most numerous (at least 17), but it is expected that many of these mounds contain aceramic levels as well. A gradual transition between the aceramic and ceramic Neolithic periods is suggested to have taken place in the second half of the 7 th millennium B.C. Only few sites (5 at present) have yielded no ceramics at all on the surface

(55) COPELAND, 1979.

(56) AKKERMANS, 1984 and forthcoming. but solely stone ware and lithic implements of PPNB tradition, and are considered to belong entirely to the aceramic Neolithic.

The vast majority of the early Neolithic sites are found in the northern parts of the Balikh valley. At present, only four sites are known from the middle and lower Balikh basin (fig. 2). Interestingly enough, the three southern-most sites are all aceramic; only one of them (Khirbet al-Bassal) also yielded some Halaf pottery, which seems to belong to the later stages of the Halaf period (early 5 th millennium B.C). No ceramics comparable to those from Assouad or Damishliyya were found at these southern sites, which strongly suggests that these settlements were deserted around the middle of the 7 th millennium B.C. Apparently, at this time the lower Balikh became wholly devoid of permanent settlement, the reasons of which are not yet clear. It should be recalled that the lower Balikh region nowadays is an arid zone having an average annual precipitation of less than $200 \mathrm{~mm}$. Agriculture here is possible only with the help of irrigation. Van Zeist and Woldring (57) have suggested that around 6000 B.C. environmental conditions in northern Syria deteriorated, the climate becoming increasingly drier and closely resembling modern-day circumstances. Perhaps an increasing aridity made permanent settlement on an agricultural basis impossible and forced Neolithic people to evacuate the lower Balikh region (58)

The middle Balikh region is dominated by the large site of Mounbatah (59). This site actually is the largest prehistoric complex in the Balikh valley, covering in total an area of perhaps 30 ha. The complex consists of at least five mounds, each clearly recognizable although they have partly merged into each other. The various mounds were not all occupied simultaneously; occupation apparently shifted through time. The complex as a whole seems to have been inhabited continuously from the early 7 th to the middle of the 5 th millennium B.C.

The clustering of small mounds is a characteristic feature of Neolithic settlements in the Balikh valley. At Sabi Abyad, it was found that the main mound consisted of at least four smaller mounds whereas three others are present within a distance of less than a hundred $\mathrm{m}$. About $6 \mathrm{~km}$ south of Sabi Abyad another cluster of prehistoric mounds is present, named Tulul Breilat, which seems to date wholly in the 7th millennium B.C. In the case of Damishliyya, another small mound, probably occu-

(57) VAN ZEIST and WOLDRING, 1980.

(58) Fragments of stone vessels and numerous flint and obsidian implements, including arrowheads of Byblos Point-type and sickle blades showing a gloss, closely compare with the artefacts from Assouad and Damishliyya and suggest that the sites in the lower Balikh were based on a similar subsistence economy as those in the north.

(59) See COPELAND, 1979, 1982. 


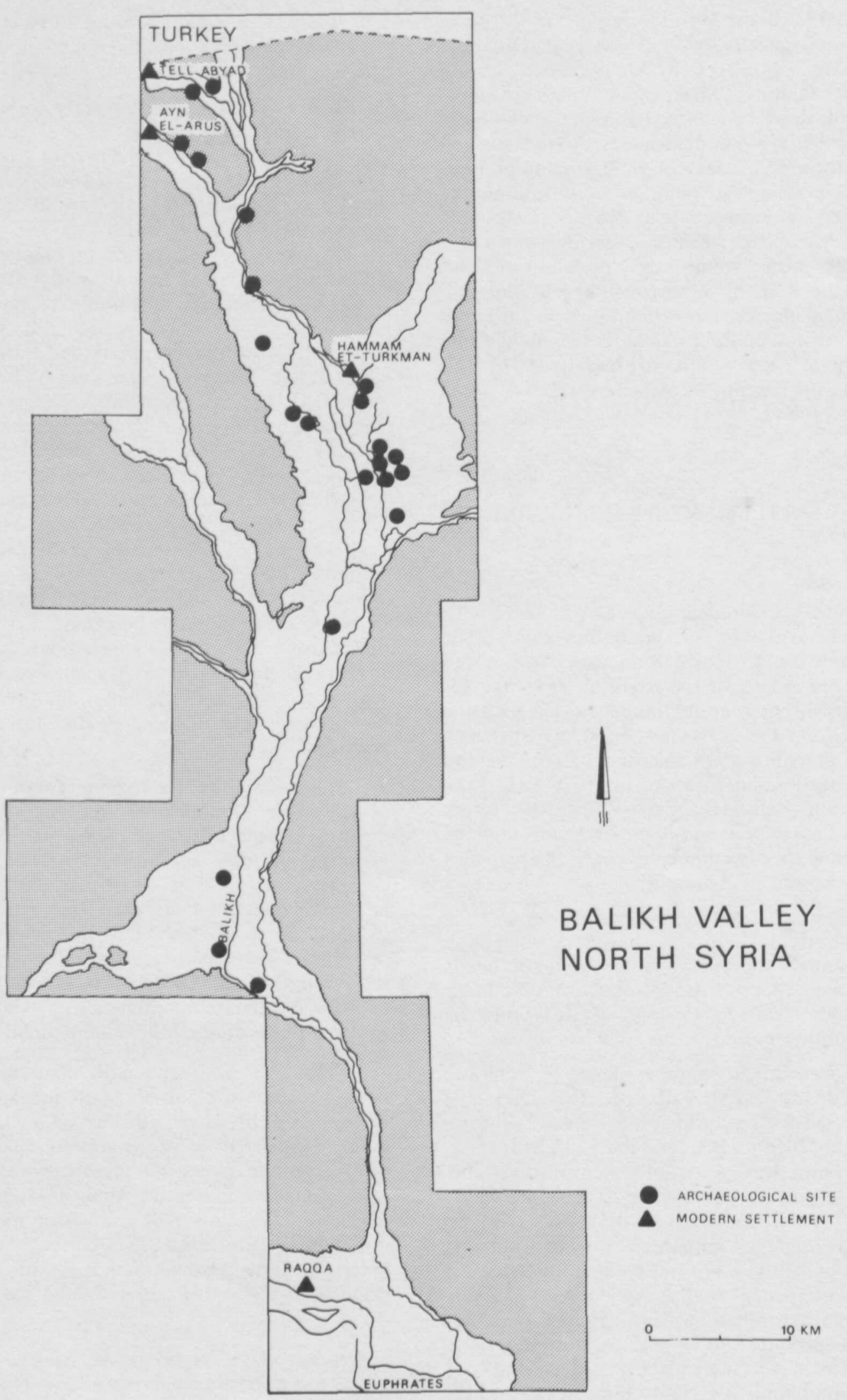

FIG. 2. - Distribution of 7th millennium settlements in the Balikh valley. 
pied simultaneously, is found only about $500 \mathrm{~m}$ to the north. Further north, Tell Assouad, too, consists of two largely contemporarily inhabited mounds which seem to have merged. Finally, near Tell Abyad on the Syro-Turkish border two Neolithic sites are found opposite each other on the banks of the Nahr Julab. Here the site on the west bank seems to be wholly aceramic, whereas the other, on the east bank, has yielded 7 th millennium ceramics. Concluding, it seems clear that whereas in some agglomerations the various mounds were occupied simultaneously, at others a shift in occupation is perceptible from one site to another. The reasons for the grouping of Neolithic sites in the Balikh valley is not fully understood. Perhaps socio-economic variables played a role. Kin-related groups may have occupied a specific area, passed on from generation to generation and clearly distinguished from that of other families. Most Neolithic mounds in the Balikh valley, both those found solitary and in clusters, are of small size, generally covering an area between 0.4 and 1 ha (60) Our excavations at Tell Damishliyya and Tell Sabi Abyad have given evidence that such small mounds contained only few and scattered permanent structures per building phase, separated by open areas. Perhaps each mound was covered by only one or two extended house complexes. Large and wellplanned settlements like, e.g., Bouqras are absent in the Balikh region.

No doubt, the clustering of Neolithic sites is related to environmental circumstances in the valley, too. The presence of water seems to be of ultimate importance for the choice of settlement location. All Neolithic settlements are found in the immediate vicinity of the Balikh or its major wadis. Obviously, some areas along the various water-courses are more suited for occupation than others. Thus, for example, no prehistoric sites are found in the plain west of the modern village of Hammam et-Turkman (on the east bank of the Balikh) which, due to its relatively low altitude and the presence of numerous waterchannels, was probably a swampy area (even nowadays parts of this region are hardly accessible after the winter rains). All Neolithic sites in the region south of Hammam et-Turkman are located along the Nahr et-Turkman and the Wadi al-Khadar, at a distance of several kilometres from the Balikh. It is suggested that here extensive marshes along the Balikh prohibited any settlement closer to the river. Only in the early 5 th millennium B.C. (Late Halaf) two small settlements were founded in this area.

Around 6000/5900 B.C. important changes seem to have taken place in settlement organisation in the

(60) Some mounds cover larger areas but it may very well be possible that these larger mounds actually consist of several smaller but merged tells, now hidden from view (as at Sabi Abyad). Moreover, the larger sites all give evidence of occupation during more than one period, thus masking the actual settlement size per period.
Balikh valley. Whereas the southern Balikh already had been evacuated at an earlier stage (before the introduction of pottery in the region), at this time many of the small settlements in the northern Balikh were deserted. An end seems to have come to a flourishing early Neolithic society and occupation now seems to have contracted to a few sites only. At present, only two sites, viz. Mounbatah and Sabi Abyad, are thought to have been permanently inhabited during the 6th millennium B.C. (61). At Sabi Abyad, the early 6 th millennium levels have not yet been reached and, consequently, little is known at present about this phase. At Mounbatah, we found a number of thick-walled, dark-red burnished ceramics on the surface together with incised sherds and pottery displaying coarsely executed geometric designs in red paint on a whitish slip. This pottery is wholly different from the 7th millennium Balikh ceramics. Le Mière (62) suggested a relationship between the Mounbatah ceramics and those of Bouqras, thus confirming a date in the early 6 th millennium B.C. Some red-burnished jar fragments have turned up in the earliest Neolithic levels reached at Tell Sabi Abyad and also some incised pottery has been found there. Incision seems to be limited to the early 6th millennium in the region. It was found neither in the earliest ceramic period (Assouad-Damishliyya) nor in the later part of the Neolithic (Halaf period). Incised pottery is found in small numbers at some sites in the Balikh valley. The apparent absence of any associated building remains of substantial nature at most of these sites may suggest that we are here dealing with nomadic groups, occupying the various small mounds for a short period only, while a few large mounds (Mounbatah, Sabi Abyad, etc.) functioned as permanent settlements. In this respect it is recalled that at Assouad the lower levels VIII-VII are followed by layers giving evidence of a strong emphasis upon hunting. Apparently a larger territorium was now exploited, requiring an increasingly mobile population. Whereas most sites with early ceramics were deserted around 6000 B.C., occupation at Assouad may have continued for some time although on a different economic basis.

The later stages of the Neolithic in the Balikh valley comprise the development of Halaf society. At present, traces of Halaf occupation were found at 28 mounds in the valley (fig. 3), although, of course, not all these sites were occupied simultaneously. Our excavations at Sabi Abyad have indicated that Halaf is a local development in the Balikh region, emerging out of an earlier Neolithic society in the second half of the 6th millennium B.C. (63). At present, only two sites, viz. Sabi Abyad and Mounbatah, definitely include Early Halaf levels but

(61) Perhaps some more sites will be known after completion of the survey analysis.

(62) LE MIÈRE, 1986 : 79-80.

(63) AKKERMANS, $1987 \mathrm{~b}$. 


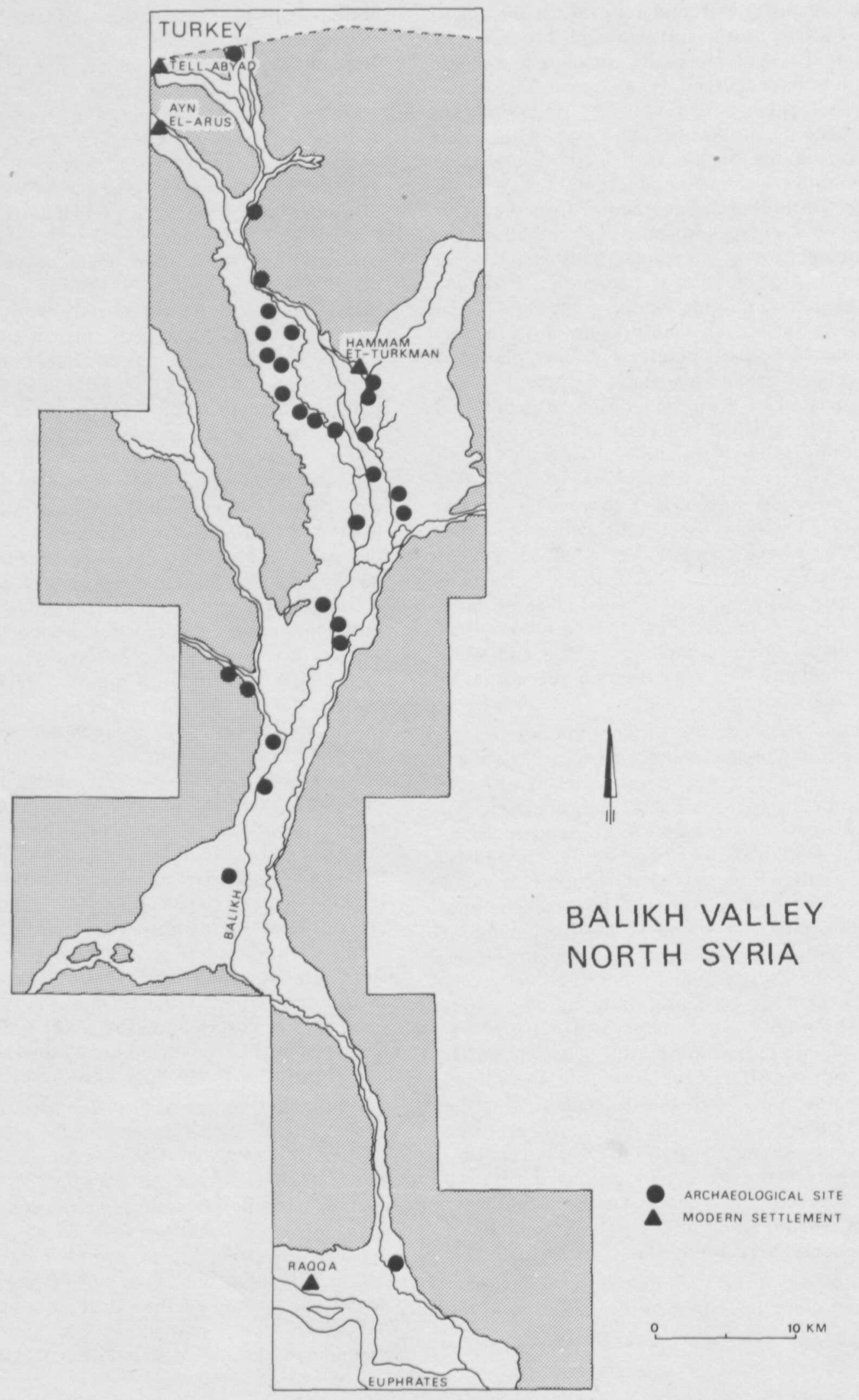

FIG. 3. - Distribution of Halaf settlements in the Balikh valley. 
more sites are expected. Sabi Abyad was deserted for some reason at the end of the Early Halaf period, but at Mounbatah no such break in occupation seems to be present. The latter site is the largest Halaf settlement in the Balikh valley, covering an area of almost 15 ha. Halaf occupation at Mounbatah includes one of the mounds of the complex and a vast area in front of this mound. About $1 \mathrm{~km}$ southwest of Mounbatah another important Halaf settlement is present (Tell as-Sawwan). The present evidence suggests that the region around Mounbatah represented the socio-economic center of Halaf occupation in the Balikh valley. Probably, the other Halaf settlements in the region were strongly oriented towards Mounbatah.

As in the earlier Neolithic, the majority of the small Halaf settlements are found along the major water-courses in the upper Balikh region. Most interesting, however, is the reoccupation of the southern Balikh valley. This region, uninhabited since about 6500 B.C., was occupied on a limited scale in the early 5 th millennium B.C. (fig. 3). Whether climatic conditions were improving around 5000 B.C. or whether Halaf technology enabled a more effective use of available water, thus allowing small-scale irrigation agriculture, is unknown.

In settlement size, Halaf sites also resemble their earlier counterparts. Most sites seem to be very small and probably were inhabited by few people only. Whereas in some cases settlements were newly founded, in other instances formerly inhabited mounds were reoccupied. Excavations at Tell Damishliyya have given evidence of a possible Halaf camp site, repeatedly visited over a number of years (64). Several other sites in the valley seem to resemble Damishliyya closely and a two-fold division in settlement organisation is suggested, with relatively large, long-term settlements like Sabi Abyad and Mounbatah on the one hand and small, temporarily occupied sites like Damishliyya on the other hand. As noted before, a similar dichotomy in settlement organisation seems to exist already in the early 6 th millennium B.C.

Peter M.M.G. AKKERMANS

A.E. Van Giffen Instituut Voor Prae en Protohistorie Singel 453

Amsterdam, Nederland

\section{Bibliography}

\section{AKKERMANS P.M.M.G.}

1984 Archäologische Geländebegehung im Balih-Tal. Archiv für Orientforschung $31: 188-190$.

1987 Tell Sabi Abyad : preliminary report on the 1986 excavations. Akkadica $52: 10-28$.

(64) AKKERMANS, in press. 1987b A Late Neolithic and Early Halaf village at Sabi Abyad, northern Syria. Paléorient 13: 23-40.

1988 The soundings at Tell Damishliyya. In : VAN LOON M.N.,(ed)., Hammam et-Turkman, I : 19-67. Istanbul : Nederlands Historisch-Archeologisch Instituut.

AKKERMANS P.M.M.G., (ed.)

1989 Excavations at Tell Sabi Abyad. Prehistoric investigations in the Balikh valley, northern Syria. BAR Int Ser. 468. Oxford.

in prep. An archaeological survey of the Balikh valley.

BRAIDWOOD R.J. and BRAIDWOOD L.S.

1960 Excavations in the Plain of Antioch, I. OIP LXI. Chicago : University of Chicago Press.

BRAIDWOOD R.J. and HOWE B.

1960 Prehistoric investigations in Iraq Kurdistan. SAOC 31. Chicago : University of Chicago Press.

CAUVIN J.

1972 Sondage à Tell Assouad (Djézireh, Syrie). Annales Archéologiques Arabes Syriennes 22: 85-88.

1974 Les débuts de la céramique sur le Moyen-Euphrate nouveaux documents. Paléorient 2 : 199-205.

CAUVIN M.-C.

1972 Note préliminaire sur l'outillage lithique de Tell Assouad (Djezireh). Annales Archéologiques Arabes Syriennes 22 : 90-93.

COPELAND L.

1979 Observations on the prehistory of the Balikh valley. Syria, during the 7 th to 4 th millennium B.C. Paléorient $5: 251-275$.

1982 Prehistoric tells in the lower Balikh valley, Syria : report on the survey of 1978. Annales Archéologiques Arabes Syriennes 32: 251-271.

1989 The flint and obsidian artifacts of Tell Sabi Abyad. In : AKKERMANS P.M.M.G., (ed.), op. cit. : 237 284.

DAVIDSON T.E.

1977 Regional variation within the Halaf ceramic tradition. Edinburgh : University of Edinburgh.

DAVIDSON T.E. and WATKINS T.

1981 Two seasons of excavation at Tell Aqab in the Jezirah, n.e. Syria. Iraq $43: 1-18$.

HALSTEAD P.

1981 Counting sheep in Neolithic and Bronze Age Greece. In : HODDER I. et al., (eds.), Pattern of the past : studies in honour of David Clarke : 307 339. Cambridge : Cambridge University Press.

HALSTEAD P. and JONES G.

1980 Early Neolithic economy in Thessaly : some evidence from excavations at Prodromos. Anthropologika 1 : 93-117.

HELMER D.

1985 Étude de la faune de Tell Assouad (Djezireh-Syrie). Sondage J.Cauvin. Cahiers de l'Euphrate $4: 275$ 285. Paris : ADPF.

\section{LE MIËRE M.}

1979 La céramique préhistorique de Tell Assouad, Djezireh, Syrie. Cahiers de l'Euphrate 2 : 3-76. Valbonne : CRA.

1986 Les premières céramiques du Moyen-Euphrate. Thèse de doctorat. Lyon : Université Lumière-Lyon 2.

1989 Clay analyses of the prehistoric pottery : first results. In : AKKERMANS P.M.M.G., (ed.), op. cit. 233-235. 


\section{MALLOWAN M.E.L.}

1946

Excavations in the Balikh valley, 1938. Iraq $8: 11$ 159.

\section{MELLAART J.}

1970 The earliest settlements in Western Asia from the ninth to the end of the fifth millennium B.C. Cambridge Ancient History I : 248-303.

1981 The prehistoric pottery from the Neolithic to the beginning of EB IV. In : MATTHERS J., (ed.), The river Qoueiq, northern Syria, and its catchment. BAR int. Ser. 98, 131-319. Oxford.

MOORE A.M.T.

The excavation of Tell Abu Hureyra in Syria : a preliminary report. Proceedings of the Prehistoric Society 41 : 50-77.

1982 A four-stage sequence for the Levantine Neolithic, ca. 8500-3750 B.C. Bulletin of the American Schools of Oriental Research 246 : 1-34.

\section{REDMAN C.L.}

1978 The rise of civilization. San Francisco : W.H. Freeman and Company.

\section{ROODENBERG J.J.}

1986

Le mobilier en pierre de Bouqras. Istanbul : Nederlands Historisch-Archeologisch Instituut.
VAN LOON M.N. (ed.)

1988 Hammam et-Turkman, I. Istanbul : Nederlands Historisch-Archeologisch Instituut.

VAN WIJNGAARDEN-BAKKER L.H.

1989 The animal remains from Tell Sabi Abyad - square P14. In : AKKERMANS P.M.M.G., (ed.), op. cit. : 301-323.

VAN ZEIST W. and WATERBOLK-VAN ROOYEN W.

1989 Plant remains from Tell Sabi Abyad. In : Akkermans P.M.M.G., (ed.), op. cit. : 325-335.

VAN ZEIST W. and WOLDRING $\mathrm{H}$.

1980 Holocene vegetation and climate of northwestern Syria. Palaeohistoria 22: 111-125.

VAN ZEIST W. et al.

1988 Some notes on the plant husbandry of Tell Hammam et-Turkman. In : VAN LOON M.N., (ed.), Hammam et-Turkman, I : 705-715. Istanbul : Nederlands Historisch-Archeologisch Instituut.

VOGEL J.C. and WATERBOLK H.T.

1964 Groningen radiocarbon dates V. Radiocarbon 6 : 349-369.

\section{VON OPPENHEIM M.}

1943

Tell Halaf I : die prähistorischen Funde. Berlin : Walter de Gruyter and Co. 